\title{
EFFECTIVENESS OF RAPESEED PRESS CAKE (RPC) IN SOW FEEDING IN TWO REPRODUCTION CYCLES*
}

\author{
Ewa Hanczakowska ${ }^{1}$, Karol Węglarzy², Małgorzata Bereza² \\ 'Department of Animal Nutrition and Feed Science, National Research Institute of Animal Production, \\ 32-083 Balice n. Kraków, Poland \\ ${ }^{2}$ Experimental Station of the National Research Institute of Animal Production, Grodziec Śląski Ltd. \\ 43-386 Świętoszówka, Poland
}

\begin{abstract}
The possibility of replacing soybean meal with rapeseed press cake (RPC) in feed was determined over two reproductive cycles in an experiment with 54 pregnant and lactating sows allocated to three groups with 18 gilts per group. Group I received the standard mixture, group II received RPC as the main protein source from insemination to 100 days of pregnancy, and the control diet during late pregnancy and lactation. In group III, RPC replaced all of soybean meal protein in early pregnancy and one-half of soybean meal protein during late pregnancy and lactation. Half of the sows in each group received a iodine supplement $(1 \mathrm{mg} / \mathrm{kg}$ feed). Sows were weighed at mating, farrowing and weaning. Piglets were weighed at 1 and 28 days of age (weaning). Samples of milk were collected at 14 days postpartum to determine the content of protein, fat, lactose and iodine. After the first reproductive cycle sows were mated and allocated to the respective groups as in the first cycle. Neither RPC nor iodine had any effect on body weight of the sows. RPC had a beneficial effect on body weight of piglets at birth and weaning, which could be due to a higher content of fat and amino acids in sow RPC diets. RPC, especially when given throughout pregnancy and lactation significantly lowered iodine content in sow milk. Piglets grew significantly faster in the second compared to the first reproductive cycle (184 and $178 \mathrm{~g}$ per day, respectively). Iodine supplemented to sows reduced piglet daily weight gain from 185 to $177 \mathrm{~g}$. It is concluded that rapeseed press cake can replace soybean meal in the diets for pregnant and lactating sows without a negative effect on their performance while improving piglet body weight.
\end{abstract}

Key words: sows, piglets, rapeseed press cake, iodine

Rapeseed is a popular protein source in animal nutrition. Its relatively high content of sulphur amino acids (Bos et al., 2007) makes it a good supplement for other feeds of plant origin that are usually poor in these amino acids. Recently, rape has also been cultivated as raw material for biofuel production (Dewulf et al., 2005). The main product remaining after oil extraction is pressed cake which contains

*This study was financed from statutory activity, project no. 2304.1. 
$25-31 \%$ of protein and $9-21 \%$ of fat depending on pressing conditions (Smulikows$\mathrm{ka}, 2004)$. The introduction of excessive amounts (25\%) of rapeseed cake into pig feeds reduced body weight gains (Turyk et al., 2003) probably due to antinutritional substances present in rapeseed.

Caution should be exercised when rapeseed cake is used in sow and piglet nutrition. Schöne et al. (2001b) found that a 15\% level of rapeseed cake in sow diets decreased feed consumption and the number of piglets born. These negative effects were not observed when the amount of rapeseed cake was lowered to 7.5\%. According to Raj (1992), rapeseed cake and whole rapeseed are not good protein sources for piglets and young pigs.

Lee et al. (1985) found no negative effect of glucosinolates on reproductive indices of gilts when their content in feed was lower than $1.8 \mathrm{~g}$ per $\mathrm{kg}$, but higher amounts can delay oestrus in gilts, lower the weight of piglets and reduce their survival to weaning.

Feeding pregnant sows high-glucosinolate rapeseed with no iodine addition accelerates the incidence of iodine deficiency syndrome (Devilat and Skoknic, 1971) and according to Schöne et al. (2001a), even small quantities of rapeseed feed and glucosinolate seem to require iodine to be supplemented at more than $1000 \mu \mathrm{g}$ per $\mathrm{kg}$ of diet.

As the new, improved varieties of rape were obtained concurrently with increased biofuel production, greater amounts of better-quality rapeseed cake are available on the market. Rapeseed cake is also one of protein sources which can be used to feed organically farmed animals. Thus, the aim of this experiment was to determine the possibility of feeding rapeseed cake with or without iodine supplement to pregnant and lactating sows in two reproductive cycles.

\section{Material and methods}

All methods used in this experiment were accepted by the Local Ethics Commission for Experiments on Animals.

\section{Animals and feed}

The experiment was performed on 54 Polish Large White primiparous gilts in two reproductive cycles. Gilts were mated to a boar of the same breed and allocated to three groups of 18 gilts each. At the beginning of the experiment the gilts weighed $122.7,122.3$ and $130.7 \mathrm{~kg}$ in groups I, II and III, respectively. These differences were not significant. Group I (control) received the standard mixture with soybean meal as the main protein source during pregnancy and lactation of the first and second cycle (Control-P and Control-L). Group II was fed RPC as the main protein source from mating to 100 days of pregnancy. In group III, RPC replaced all of soybean meal protein in early pregnancy and one-half of soybean meal protein during late pregnancy and lactation (RPC-P and RPC-L). Half of the sows in each group (9 animals) received a iodine supplement $(1 \mathrm{mg} / \mathrm{kg}$ feed). 
Sows were housed individually from mating to 100 days of pregnancy. At 100 days of pregnancy sows were moved to the farrowing house and kept also in individual pens until weaning of piglets.

Rapeseed cake was produced in an on-farm biofuel production plant (Experimental Station Grodziec Śląski, south-west Poland). The composition of feed mixtures for sows is given in Table 1 .

Table 1. Composition and nutrient content of the experimental diets for sows $\left(\mathrm{g} \times \mathrm{kg}^{-1}\right)$

\begin{tabular}{|c|c|c|c|c|}
\hline \multirow{2}{*}{ Item } & \multicolumn{2}{|c|}{ Pregnant sows } & \multicolumn{2}{|c|}{ Lactating sows } \\
\hline & $\mathrm{CP}$ & $\mathrm{RP}$ & $\mathrm{CL}$ & RL \\
\hline Barley (ground) & 527.5 & 496.5 & 293.5 & 231.7 \\
\hline Wheat (ground) & 150 & 150 & 200 & 200 \\
\hline Corn meal & & & 120 & 120 \\
\hline Triticale & 100 & 100 & 100 & 100 \\
\hline Wheat bran & 100 & 100 & 50 & 50 \\
\hline Soybean meal & 50 & & 180 & 100 \\
\hline Rapeseed press cake & & 80 & & 140 \\
\hline Dried grass & 50 & 50 & 30 & 30 \\
\hline Dicalcium phosphate & 5 & 6 & 6 & 8 \\
\hline Calcium carbonate & 9 & 9 & 10 & 10 \\
\hline Premix $0.5 \% *$ & 5 & 5 & 5 & 5 \\
\hline Salt & 3.5 & 3.5 & 4.5 & 4.5 \\
\hline L-lysine & & & 1 & 0.8 \\
\hline \multicolumn{5}{|l|}{ Nutrient content per kg: } \\
\hline metabolizable energy $(\mathrm{MJ})^{* *}$ & 11.8 & 11.9 & 12.4 & 12.3 \\
\hline dry matter $(\mathrm{g})$ & 883.1 & 882.9 & 861.2 & 872.0 \\
\hline crude protein $(\mathrm{g})$ & 114.3 & 115.0 & 160.2 & 153.2 \\
\hline crude fat $(\mathrm{g})$ & 28.7 & 38.7 & 22.2 & 41.3 \\
\hline crude fibre $(\mathrm{g})$ & 39.1 & 41.3 & 41.6 & 49.2 \\
\hline Lys (g) & 5.11 & 5.45 & 8.36 & 8.86 \\
\hline Met + Cys (g) & 4.57 & 4.97 & 5.43 & 6.16 \\
\hline $\operatorname{Thr}(\mathrm{g})$ & 4.41 & 4.80 & 5.69 & 6.26 \\
\hline $\operatorname{Trp}(\mathrm{g})$ & 1.52 & 1.89 & 2.03 & 2.66 \\
\hline glucosinalates $(\mu \mathrm{mol})$ & & 1.89 & & 3.30 \\
\hline
\end{tabular}

Explanations:

* vitamin-mineral premix used for pregnant sows - vitamin: A - $200000 \mathrm{IU} ; \mathrm{D}_{3}-20000 \mathrm{IU}$; E - $10.0 \mathrm{~g}$; $\mathrm{K}_{3}-0.4 \mathrm{~g} ; \mathrm{B}_{2}-0.8 \mathrm{~g} ; \mathrm{B}_{6}-0.4 \mathrm{~g} ; \mathrm{B}_{12}-0.004 \mathrm{~g}$; pantothenic acid $-2.0 \mathrm{~g}$; choline chloride $-50 \mathrm{~g}$; folic acid $0.2 \mathrm{~g}$; nicotinic acid $-4.0 \mathrm{~g}$; biotin $-0.03 \mathrm{~g}$; magnesium $-8.0 \mathrm{~g}$; manganese $-5.0 \mathrm{~g}$; iodine $0.08 \mathrm{~g}$; zinc $15.0 \mathrm{~g}$; iron $-18.0 \mathrm{~g}$; copper $-4.0 \mathrm{~g}$; cobalt $-0.08 \mathrm{~g}$; selenium $-0.04 \mathrm{~g}$;

* vitamin-mineral used premix for lactating sows - vitamin: A - $240000 \mathrm{IU}$; D3 - $20000 \mathrm{IU} ; \mathrm{E}-10.0 \mathrm{~g}$; $\mathrm{K}_{3}-0.4 \mathrm{~g} ; \mathrm{B}_{2}-0.8 \mathrm{~g} ; \mathrm{B}_{12}-0.004 \mathrm{~g}$; pantothenic acid $-2.0 \mathrm{~g}$; choline chloride $-50 \mathrm{~g}$; folic acid $-0.4 \mathrm{~g}$; nicotinic acid $-4.0 \mathrm{~g}$; biotin $-0.04 \mathrm{~g}$; magnesium $-8.0 \mathrm{~g}$; manganese $-10.0 \mathrm{~g}$; iodine $-0.2 \mathrm{~g}$; zinc $-14.0 \mathrm{~g}$; iron $16.0 \mathrm{~g}$; copper $-4.0 \mathrm{~g}$; cobalt $-0.1 \mathrm{~g}$; selenium $-0.04 \mathrm{~g}$;

** ME calculated using the equation of Hoffmann and Schiemann (1980).

Sows received $2.5 \mathrm{~kg}$ of mixture per day from mating to 100 days of pregnancy and $3.5 \mathrm{~kg}$ from 100 days of pregnancy to farrowing. During lactation the administered amount of feed depended on litter size. Water was available ad libitum. Sows were weighed at mating, farrowing and weaning. Piglets were weighed individually 
at 1 and 28 days of age (weaning). Their feed intake was also measured. The composition of piglet feed is given in Table 2 .

Table 2. Composition of diets for piglets $\left({\left.\mathrm{g} \times \mathrm{kg}^{-1}\right)}^{-1}\right.$

\begin{tabular}{lc} 
Barley (ground) & 200 \\
Wheat (ground) & 270.5 \\
Corn meal & 200 \\
Soybean meal & 210 \\
Milk powder & 40 \\
Dried whey & 50 \\
Premix* & 5 \\
Salt & 2 \\
Calcium carbonate & 10 \\
Dicalcium phosphate & 6 \\
L-lysine & 1.5 \\
Acidifier & 5 \\
& \\
Content of nutrients in 1 kg mixture: & \\
$\quad$ metabolizable energy $(\mathrm{MJ})$ & 12.9 \\
$\quad$ dry matter $(\mathrm{g})$ & 885 \\
$\quad$ crude protein $(\mathrm{g})$ & 173 \\
$\quad$ crude fat $(\mathrm{g})$ & 31 \\
$\quad$ crude fibre $(\mathrm{g})$ & 17 \\
$\quad$ crude ash $(\mathrm{g})$ & 48 \\
$\quad$ Lysine $(\mathrm{g})$ & 10.03 \\
Methionine + cystine $(\mathrm{g})$ & 5.98 \\
\hline
\end{tabular}

* Premix composition: vitamin: A - $2700000 \mathrm{IU} ; \mathrm{D}_{3}-400000 \mathrm{IU}$; E - $8.0 \mathrm{~g} ; \mathrm{K}_{3}-0.5 \mathrm{~g} ; \mathrm{B}_{1}-0.5 \mathrm{~g} ; \mathrm{B}_{2}-$ $0.8 \mathrm{~g} ; \mathrm{B}_{6}-0.8 \mathrm{~g} ; \mathrm{B}_{12}-0.008 \mathrm{~g}$; pantothenic acid $-2.8 \mathrm{~g}$; choline chloride $-70 \mathrm{~g}$; folic acid $-0.2 \mathrm{~g}$; nicotinic acid - 5.0; magnesium $-10 \mathrm{~g}$; manganese $-12 \mathrm{~g}$; iodine $-0.1 \mathrm{~g}$; zinc $-30 \mathrm{~g}$; iron $-20 \mathrm{~g}$; copper $-32 \mathrm{~g}$; cobalt $0.06 \mathrm{~g}$; selenium $-0.04 \mathrm{~g}$; complete limestone to $1000 \mathrm{~g}$.

During lactation (day 14) about $100 \mathrm{ml}$ samples of milk were obtained by hand milking of all mammary glands after intramuscular application of oxytocin. Their content of iodine, protein, fat and lactose was analysed. On the same day blood was sampled to analyse serum iodine content.

After the first reproductive cycle, i.e. after weaning, sows were mated again and allocated to the respective groups.

\section{Chemical analyses}

Gross composition of feed was analysed according to AOAC (2005). Amino acids were analysed using an INGOS AAA 400 automatic analyser. Glucosinolates content in rapeseed press cake was determined using HPLC method (PN-EN ISO 91-67-1).

Crude protein, crude fat and lactose content in milk was estimated with a Funke Gerber LactoStar analyser. Iodine content in milk and blood was analysed by the catalytic-kinetic method with spectrophotometric measurement, P019 ver. 12 from 12 November 2007. 


\section{Statistical analysis}

Statistical analysis of treatment effects was performed with a three-factor analysis of variance (ANOVA) with comparison of means by Duncan's multiple range test at $\mathrm{P}<0.05$ and $\mathrm{P}<0.01$ levels of significance using the Statistica $\mathrm{v} 5.1$ package.

\section{Results}

Gross composition and glucosinolates content of RPC used are presented in Table 3.

Table 3. Chemical composition and glucosinolates content of rapeseed cake

\begin{tabular}{lr}
\hline Dry matter $\left(\mathrm{g} \cdot \mathrm{kg}^{-1}\right)$ & 887 \\
crude protein $\left(\mathrm{g} \cdot \mathrm{kg}^{-1} \mathrm{DM}\right)$ & 291 \\
crude fat & 137 \\
crude ash & 59 \\
crude fibre & 119 \\
$\mathrm{NDF}$ & 230 \\
ADF & 172 \\
ADL & 63 \\
Glucosinolates $(\mu \mathrm{mol} / \mathrm{g} \mathrm{DM})$ & 23.6
\end{tabular}

Rapeseed cake had no effect on body weight of sows (Table 4). There was also no significant difference in time which passed from weaning to successful mating (from 14.6 to 17.9 days). Iodine supplement also had no effect on sow body weights. At the beginning of the second reproductive cycle sows were heavier $(149.8 \mathrm{~kg})$ than in the first cycle $(125.5 \mathrm{~kg})$, but they grew slowly, as a result of which body weights at weaning were similar in both cycles. Sow weight gain from mating to 100 days of pregnancy depended on the type of feed mixture and production cycle $(\mathrm{P}<0.01)$.

Rapeseed cake had a beneficial effect $(\mathrm{P}<0.01)$ on body weight of piglets at birth and weaning (Table 5). Piglets born to P sows fed only RPC had higher mean weight gains when compared to the control group $(\mathrm{P}<0.01)$ and to the $\mathrm{RPC}-\mathrm{P}+\mathrm{L}$ group $(\mathrm{P}<0.05)$. Piglets grew significantly faster in the second $(185 \mathrm{~g} / \mathrm{day})$ than in the first reproductive cycle (177 g/day). Iodine supplement lowered body weight gains of piglets from birth to weaning (from 185 to $177 \mathrm{~g} /$ day, $\mathrm{P}<0.01$ ).

The milk of sows receiving rapeseed cake (RP+RL) contained less protein $(\mathrm{P}<0.05)$ than the milk of control sows (Table 6) and the milk of $\mathrm{RP}+\mathrm{CP}$ and $\mathrm{RP}+\mathrm{RL}$ sows contained more lactose $(\mathrm{P}<0.05)$. Protein and lactose content was lower in the second reproductive cycle $(\mathrm{P}<0.01)$. RPC, especially when given throughout pregnancy and lactation, significantly reduced the iodine content of sow milk, which in this group was almost three-fold lower than that in the control group (33.47 and $11.98 \mu \mathrm{g}$, respectively). Fat, lactose and iodine content depended on the type of feed mixture and iodine supplement (interaction $\mathrm{P}<0.05$ ) and content of fat, protein and lactose in sow milk was due to the reproductive cycle $(\mathrm{P}<0.05)$. 


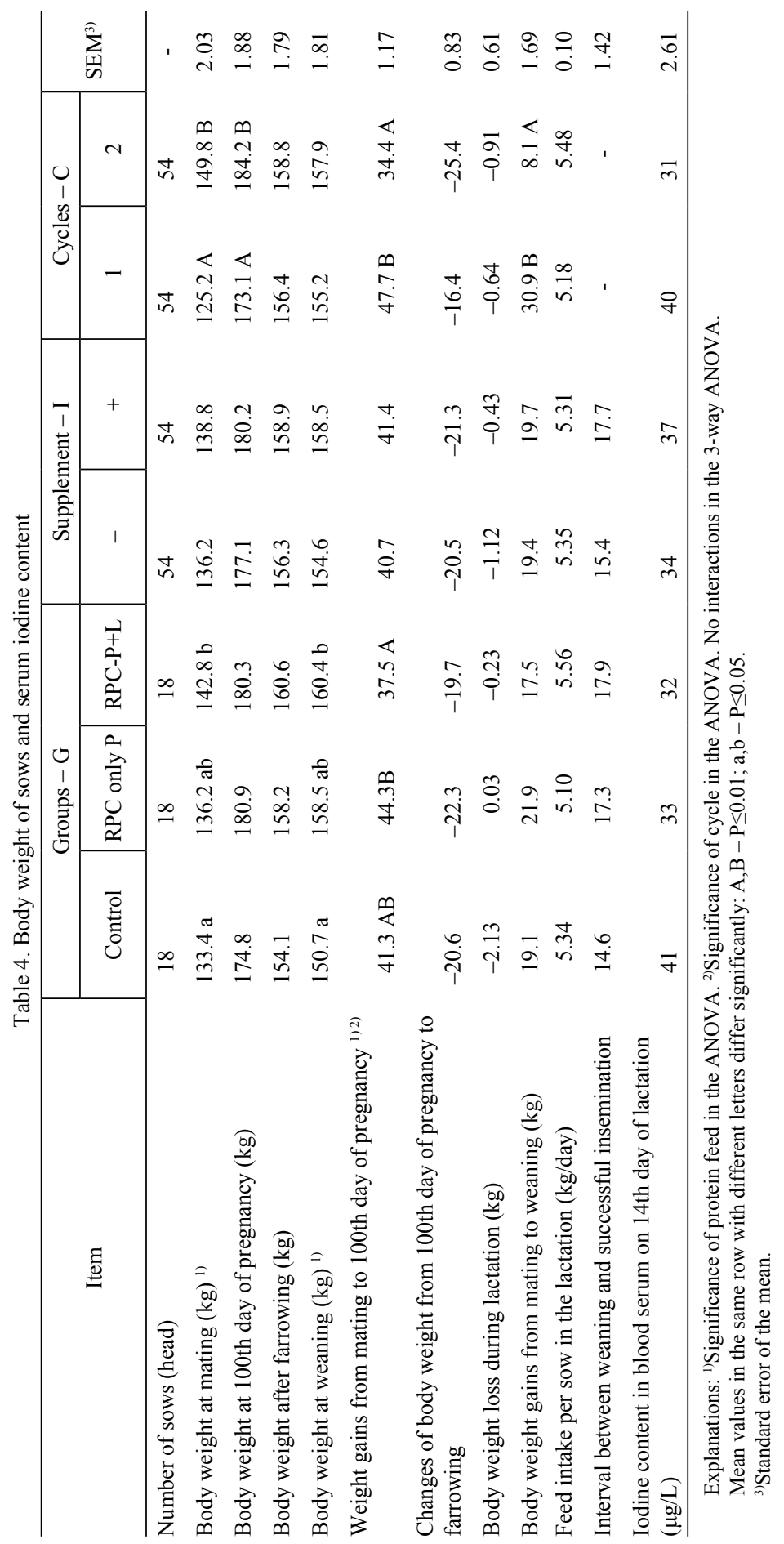



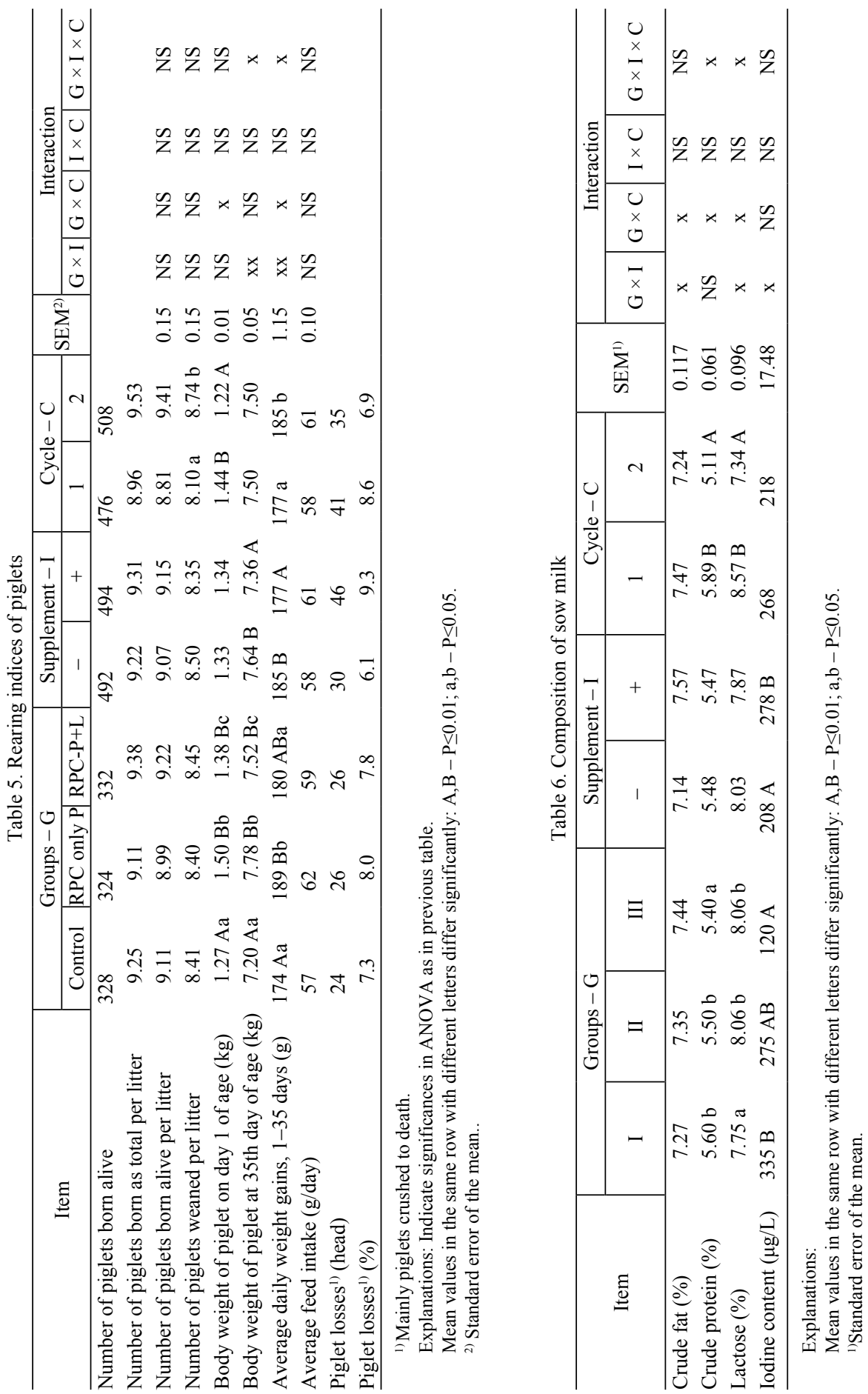


\section{Discussion}

According to the results obtained, rapeseed press cake used in a moderate dose of about $15 \%$ of feed mixture, which enables partial replacement of soybean meal, had no negative effect on the performance of sows and piglets. Different results were reported by Schöne et al. (2001 b). These discrepancies probably were due to the type of material used. Rapeseed press cake is not a standardized product and its nutritional value can differ depending on the technology used (Li et al., 2002) and the energy content of feed (Brand et al., 2000). Thus it is difficult to compare the results obtained in different experiments. However, the better performance of sows in this experiment could be due to the higher content of fat and amino acids in RPC diets.

Glucosinolates are the main antinutritional factors in rapeseed and in the experiment of Schöne et al. (2001 b) 15\% of rapeseed press cake containing $23.3 \mathrm{mmol}$ of glucosinolates per $\mathrm{kg}$ (i.e. $3.2 \mathrm{mmol}$ glucosinolates per $\mathrm{kg}$ of diet) reduced feed intake and depressed animals' weight gains. Other antinutrients, such as phenolics (Thiyam et al., 2009) are of lesser importance. Rapeseed press cake used in this experiment was a source of 1.9 (pregnant sows) or 3.3 (lactating sows) mmol of glucosinolates per $\mathrm{kg}$ of feed and it was not enough to impair sow performance. On the contrary, piglets born to sows fed with rapeseed press cake were significantly heavier than those born to control sows, although there was no difference in the number of piglets born. The weaning weight of piglets from the groups receiving rapeseed was still higher than that of the control piglets, which could result from their higher birth weight and their better weight gains, probably due to higher content of fat (not significant) and lactose $(\mathrm{P}<0.05)$ in sow milk.

RPC significantly lowered iodine content in sow milk. A similar effect was found by Schöne et al. (2001 a).

There were not many differences between the results obtained in the first and second reproductive cycles. At farrowing and at 100 days of pregnancy, sows in the second cycle were significantly heavier but their body weight gains were lower during this period. At the end of piglet weaning, there was no significant difference in sow weight. Data on the physiological aspects of the effect of antinutritive factors present in rapeseed on pig reproduction are limited (Opałka et al., 2001). Smiricky-Tjardes et al. (2003) found no effect of reproductive cycle on any response criteria measured in their study, but they used full-fat canola seeds and canola meal. Perhaps the lower weight gains of sows in the second reproductive cycle of our experiment were due to their significantly higher body weight at the beginning of this cycle, which could be strengthened by the accumulation of some antinutritive substances present in RPC. Ingested glucosinolates could be degraded by microorganisms in the digestive tract (Mawson et al., 1994) and the products of this degradation can accumulate in lungs and kidneys (thiocyanate) but also in lungs and especially in the thyroid (5-vinyl-1,3-oxazolidine-2-thione, 5-VOT) (Mabon et al., 2000).

Summing up the results of this experiment, replacing soybean meal with rapeseed press cake in the feed for pregnant and lactating sows has no negative effect on their performance and improves piglet body weight. 


\section{References}

AOAC (2005). Official methods of analysis of AOAC International, 18th Edition, Horwitz W., Latimer G. Gaithersburg, MD, USA.

Bos C., Airinei G., Mariotti F., Benamouzig R., Bérot S., Evrard J., Fénart E., Tom e D., Gaudich on C. (2007). The poor digestibility of rapeseed protein is balanced by its very high metabolic utilization in humans. J. Nutr., 137: 594-600.

Brand van den H., He etkamp M.J.W., Soede M.N., S chrama J.W., Kemp B. (2000). Energy balance of lactating primiparous sows as affected by feeding level and dietary energy source. J. Anim. Sci., 78: 1520-1528.

Devilat J., Skoknic A. (1971). Feeding high levels of rapeseed meal to pregnant gilts. Can. J. Anim. Sci., 51: 715-719.

Dewulf J., Van Langenhove H., Van De Velde B. (2005). Energy-based efficiency and renewability assessment of biofuel production. Environ. Sci. Technol., 39: 3878-3882.

H o ff m a n n L., S c h i e m a n n R. (1980). Von der Kalorie zum Joule: Neue Grössenbeziehungen bei Messungen des Energieumsatzes und bei der Berechnung von Kennzahlen der energetischen Futterbewertung. Arch. Tierernahr., 30: 733-742.

L e e P.A., H ill R., R o s s E.J. (1985). Studies on rapeseed meal from different varieties of rape in the diets of gilts. II. Effects on farrowing performance of gilts, performance of their piglets to weaning and subsequent conception of the gilt. Br. Vet. J., 141: 592-602.

Li D., P engbin X., Liming G., Shijun F., Canghai H. (2002). Determination of apparent ileal amino acid digestibility in rapeseed meal and cake processed at different temperature using the direct and difference method with growing pigs. Arch. Tierernahr., 56: 339-349.

Mabon N., Mandiki S.N.M., D ery cke G., B is ter J.L., W a the let J.P., Marlier M., $\mathrm{P}$ a qua y R. (2000). Chemical changes and influences of rapeseed antinutritional factors on lamb physiology and performance. 3. Antinutritional factors in plasma and organs. Anim. Feed Sci. Technol., 85: 111-120.

Maw s o n R., H e a n e y R.K., Z d uń c z y k Z., K o złow s k a H. (1994). Rapeseed meal-glucosinolates and their antinutritional effects. Part IV. Goitrogenicity and intestinal organs abnormalities in animals. Die Nahrung, 38: 178-191.

Opałka M., Dusza L., Koziorowski M., Staszkiewicz J., Lipiński K., Tywońc z u k J. (2001). Effect of long-term feeding with graded levels of low glucosinolate rapeseed meal on endocrine status of gilts and their piglets. Livest. Prod. Sci., 69: 233-243.

R a j S. (1992). Using of rapeseed meal, rapeseed cake and whole rape seed " 00 " in pig feeding. In: Pastuszewska B. (Ed.) Rapeseed in Animal Feeding, Omnitech Press, Warszawa, pp. 18-23 (in Polish).

Schöne F., Leiterer M., Hartung H., Jahreis G., Tis chendorf F. (2001 a). Rapeseed glucosinolates and iodine in sows affect the milk iodine concentration and the iodine status of piglets. Br. J. Nutr., 85: 659-670.

S chöne F., T is chendorf F., Le it erer M., Hartung H., B argholz J. (2001 b). Effects of rapeseed-press cake glucosinolates and iodine on the performance, the thyroid gland and the liver vitamin A status of pigs. Arch.Tierernahr., 55: 333-350.

S m i r i c k y - T j a rd e s M.R., S t e in H.H., P e t e r s D.N. (2003). The effect of canola on reproductive performance in sows. J. Anim. Sci., 81, Suppl. 1, p. 69.

S mulik ow ska S. (2004). Nutritional value and utilization of rapeseed cake in pig feeding. Proc. Conf. Utilization of By-Products of Biofuels Production in Feed Management and Animal Nutrition. Ed. National Research Institute of Animal Production, Kraków, pp. 15-23.

Th i y a m U., P i c k a rd t C., Ungew is s J., B a u m e r t A. (2009). De-oiled rapeseed and a protein isolate: characterization of sinapic acid derivatives by HPLC-DAD and LC-MS. Eur. Food Res. Technol., 229: 825-831.

T u r y k Z., O s e k M., K l o c e k B., W i t a k B. (2003). The effect of protein feeds on fattening results and post-slaughter evaluation in swine. Pol. J. Food Nutr. Sci., 12/53: 63-68. 
EWA HANCZAKOWSKA, KAROL WĘGLARZY, MAŁGORZATA BEREZA

\section{Efektywność makuchu rzepakowego (RPC) w żywieniu loch w dwóch cyklach reprodukcyjnych}

\section{STRESZCZENIE}

Badano możliwość zastąpienia śruty sojowej makuchem rzepakowym (RPC) w paszy dla ciężarnych i karmiących loch w doświadczeniu na 54 lochach w dwóch cyklach reprodukcyjnych. Zwierzęta przydzielono do trzech grup doświadczalnych po 18 loch w każdej. Grupa I otrzymywała mieszankę standardową, w grupie II od pokrycia do 100. dnia ciąży RPC był głównym źródłem białka, a w okresie wysokiej ciąży i laktacji lochy otrzymywały mieszankę taką jak w grupie kontrolnej. W grupie III w czasie niskiej ciąży białko soi było w pełni zastąpione przez RPC, a w czasie ciąży wysokiej i laktacji w połowie. Połowa loch w każdej grupie otrzymywała dodatek jodu (1 mg /1 kg paszy). Lochy były ważone w czasie krycia, po porodzie i przy odsadzeniu prosiąt. Prosięta ważono w pierwszym i 28. dniu życia (odsadzenie). W 14. dniu laktacji pobierano próbki mleka i oznaczano w nich zawartość białka, tłuszczu, laktozy i jodu. Po zakończeniu pierwszego cyklu lochy zostały pokryte i przeznaczone do odpowiednich grup, jak w cyklu pierwszym.

Ani makuchy, ani jod nie miały wpływu na masę ciała loch. Makuchy poprawiły masę ciała prosiąt przy urodzeniu i przy odstawieniu, co mogło być wynikiem wyższej zawartości tłuszczu i aminokwasów w paszy RPC dla loch. Makuchy, zwłaszcza podawane w czasie całej ciąży i laktacji, istotnie obniżyły zawartość jodu w mleku loch. Prosięta przyrastały znacznie szybciej w drugim niż w pierwszym cyklu reprodukcyjnym (odpowiednio 184 i $177 \mathrm{~g}$ dziennie). Dodatek jodu obniżył przyrosty dzienne prosiąt ze 185 do $177 \mathrm{~g}$.

Na podstawie otrzymanych wyników można stwierdzić, że makuchem rzepakowym można bez szkody zastąpić śrutę sojową w paszy dla ciężarnych i karmiących loch, uzyskując równocześnie poprawę masy ciała prosiąt. 